\title{
Pulmonary Surfactant Protein A, B, and C mRNA and Protein Expression in the Nitrofen-Induced Congenital Diaphragmatic Hernia Rat Model
}

\author{
MINKE VAN TUYL, PIETJAN E. BLOMMAART, RICHARD KEIJZER, SUSAN E. WERT, \\ JAN M. RUIJTER, WOUTER H. LAMERS, AND DICK TIBBOEL
}

\begin{abstract}
Department of Pediatric Surgery, Sophia Children's Hospital, Erasmus University Medical Center Rotterdam, 3015 GJ Rotterdam, The Netherlands [M.v.T., R.K., D.T.], Department of Anatomy and Embryology, Academic Medical Center, University of Amsterdam, 1105 AZ Amsterdam, The Netherlands [M.v.T., P.J.B., J.M.R., W.H.L.], Divisions of Pulmonary Biology and Neonatology, Children's Hospital Medical Center, Cincinnati, Ohio, 45229, U.S.A. [S.E.W.]
\end{abstract}

\begin{abstract}
Neonates with congenital diaphragmatic hernia (CDH) suffer from a diaphragmatic defect, lung hypoplasia, and pulmonary hypertension, with poor lung function forming the major clinical challenge. Despite prenatal diagnosis and advanced postnatal treatment strategies, the mortality rate of $\mathrm{CDH}$ is still high. $\mathrm{CDH}$ has been subject of extensive research over the past decades, but its etiology remains unknown. A major problem with $\mathrm{CDH}$ is the failure to predict the individual response to treatment modalities like high-frequency ventilation, inhaled nitric oxide, and extracorporeal membrane oxygenation. In this study, we tested the possibility that $\mathrm{CDH}$ lungs are surfactant protein deficient, which could explain the respiratory failure and difficulties in treating $\mathrm{CDH}$ infants. We investigated this hypothesis in the nitrofeninduced $\mathrm{CDH}$ rat model and assessed the cellular concentrations of surfactant protein (SP)-A, -B, and -C mRNA with a quantitative radioactive in situ hybridization technique. No differences were observed between control and $\mathrm{CDH}$ lungs for SP mRNA expression patterns. The cellular concentration (mean OD) of
\end{abstract}

\section{ABSTRACT}

SP-A and SP-B mRNA was similar at all stages whereas the mean OD of SP-C mRNA and the volume fraction of cells (\% Area) expressing SP mRNA was higher in $\mathrm{CDH}$ lungs at term. Immunohistochemical analysis revealed no differences between control and $\mathrm{CDH}$ lungs for SP protein expression. No differences in the mean OD or \% Area for the SP mRNAs were found between the ipsi- and contralateral side of $\mathrm{CDH}$ lungs. We conclude that there is no primary deficiency of surfactant proteins in the nitrofen-induced CDH rat model. (Pediatr Res 54: 641-652, 2003)
Abbreviations
CDH, congenital diaphragmatic hernia
RDS, respiratory distress syndrome
ECMO, extracorporeal membrane oxygenation
Nitrofen, 2,4-dichloro-phenyl-p-nitrophenyl ether
DSPC, disaturated phosphatidyl choline

$\mathrm{CDH}$ is an anomaly occurring 1 in 3000 live births (1). It is characterized by a diaphragmatic defect, severe lung hypoplasia, and pulmonary hypertension, and in $40 \%$ of the patients other severe birth defects such as cardiac abnormalities are present $(2,3)$. Despite years of extensive research, the etiology

Received October 3, 2002; accepted April 14, 2003.

Correspondence: D. Tibboel, Sophia Children's Hospital, Erasmus Medical Center Rotterdam, Dr Molewaterplein 60, 3015 GJ Rotterdam, The Netherlands; e-mail: j.illsley@erasmusmc.nl

Supported by a student's grant (M.v.T.), by the Sophia Foundation and the Ludgardina Bouman Foundation (P.E.B.), and, in part, by National Institutes of Health grant HL56387 (S.E.W.).

DOI: 10.1203/01.PDR.0000086906.19683.42 of CDH remains unknown (4). Clinically, pulmonary hypoplasia and pulmonary hypertension form the major problems in $\mathrm{CDH}(5)$.

Many CDH studies have focused on treatment modalities such as conventional ventilation with gentle handling of the fragile lung, high-frequency ventilation, ECMO, in utero tracheal ligation with or without betamethasone injection, inhaled nitric oxide, and prenatal injections of betamethasone, TSHreleasing hormone, or a combination of both hormones. Although selected centers have reported improved survival $(6,7)$, the overall mortality rate, however, is still variably high, so that $\mathrm{CDH}$ continues to be a serious problem in the neonatal and pediatric surgical intensive care unit, with optimal treatment for $\mathrm{CDH}$ still the subject of ongoing debate $(5,8-10)$. 
It is unknown why $\mathrm{CDH}$ infants can be so refractory to treatment, which makes it even more difficult to predict the outcome in the individual patient. Lungs from premature infants suffering from RDS are surfactant-deficient and major breakthroughs in the treatment of these infants were prenatal corticosteroid injections and the postnatal administration of exogenous surfactant (11-14). Surfactant is essential for proper lung function. It decreases the surface tension in the lung, thereby protecting alveoli against collapse at end-expiration (15). We realize that it is not justified to directly compare $\mathrm{CDH}$ lungs to RDS lungs, but the possibility that $\mathrm{CDH}$ lungs are surfactant-deficient is still not ruled out or proven. In human autopsy material of pulmonary hypoplasia including $\mathrm{CDH}$, normal levels of SP-A, -B, and -C protein were reported (16). Also, normal levels of phospholipids and normal lecithin/ sphingomyelin (L/S) ratios (used as indicator of fetal lung maturity) in amniotic and bronchoalveolar lavage (BAL) fluid have been reported $(17,18)$. Nevertheless, other studies have found decreased amounts of SP-A in human CDH $(19,20)$. It has to be kept in mind that a secondary surfactant deficiency may develop due to the negative effects of artificial ventilation on surfactant function after birth (21). So far, data from human and different animal CDH models (22) failed to report consistent results concerning the surfactant status in $\mathrm{CDH}$ (summarized in Table 1) (17-20, 23-39).

The most common method to determine the amount of RNA in tissue is Northern blot analysis. This method, however, requires tissue homogenization, with the result that all cellular relations are lost. Jonker et al. (40) have developed a method to quantify the signal obtained with the in situ hybridization procedure. This quantitative in situ hybridization technique allows the detection of the concentration of mRNA at the cellular level within the architecture of the tissue.

In this study, we have used this technique to accurately assess the cellular concentration of SP-A, -B, and -C mRNA in the nitrofen-induced $\mathrm{CDH}$ rat model (41). We observed no differences in the expression patterns or cellular concentration of the SP mRNAs between control and $\mathrm{CDH}$ embryonic rat lungs, except for the level of SP-C mRNA, which was higher in $\mathrm{CDH}$ than in control lungs at term [gestational day (E)22]. No differences between control and $\mathrm{CDH}$ lungs were found upon immunohistochemical visualization of the respective surfactant proteins. At term, the volume fraction of SP mRNAexpressing cells was higher in CDH lungs than in controls. Furthermore, no differences in the expression pattern, concentration of SP mRNA per cell or the volume fraction of SP mRNA-expressing cells was found between the ipsilateral (hernia) and contralateral (no hernia) side of a $\mathrm{CDH}$ lung. These results demonstrate that the embryonic rat with nitrofeninduced $\mathrm{CDH}$ is not deficient for pulmonary SP-A, -B, or -C.

\section{METHODS}

Animals. Adult Wistar rats were purchased from the Broekman Institute B.V. in Someren (The Netherlands). Rats were mated at the end of the morning (E0). To induce $\mathrm{CDH}$ and lung hypoplasia, $100 \mathrm{mg}$ of nitrofen dissolved in $1 \mathrm{~mL}$ olive oil was administered orally on E10 (term $=$ E23) $(38,41,42)$. To determine the surfactant status of lungs from embryonic rats with nitrofen-induced $\mathrm{CDH}$, we examined the expression patterns of SP-A, -B, and -C mRNA and protein in control and $\mathrm{CDH}$ fetuses of E15, 18, 20, and 22. In rat, E15 corresponds to

Table 1. Surfactant in congenital diaphragmatic hernia

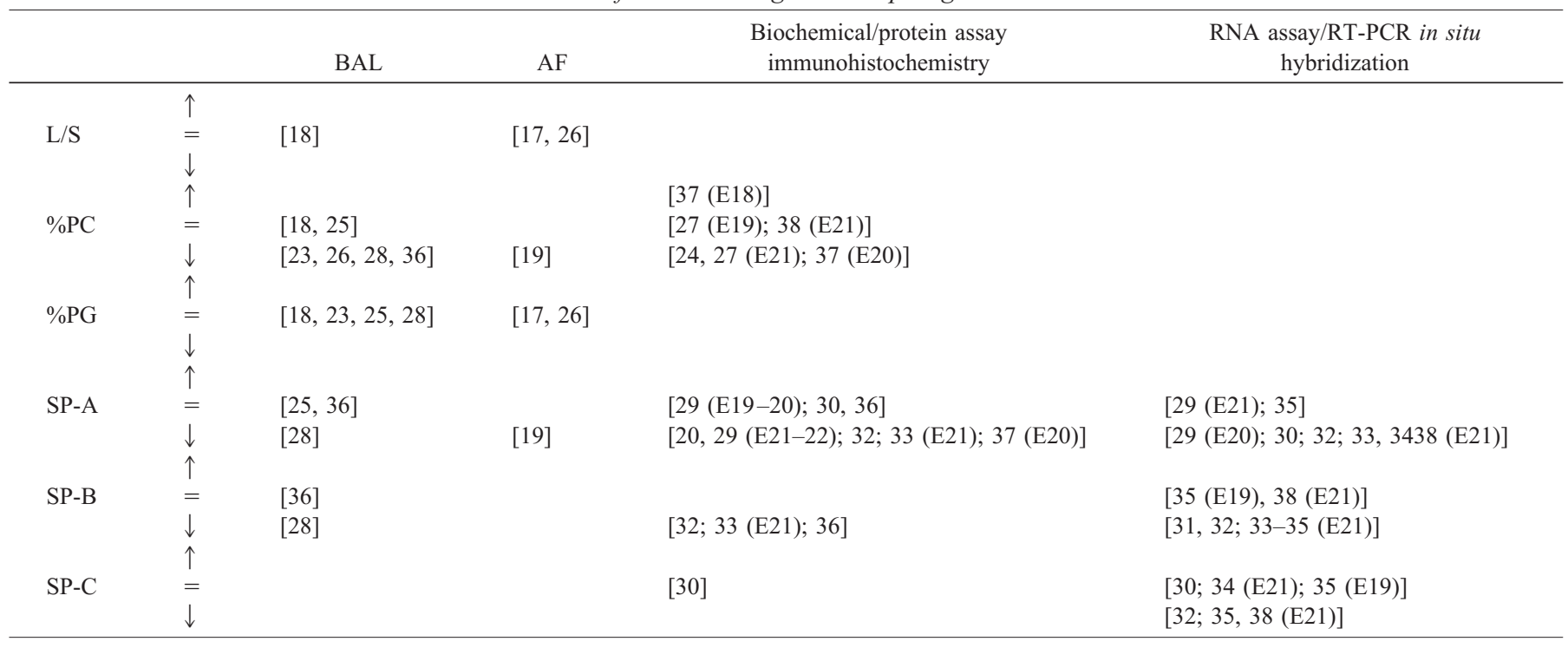

Overview of surfactant protein expression in human or experimental $\mathrm{CDH}$. Numbers between square brackets indicate citations as listed in the references section. In $\mathrm{CDH}$, lecithin/sphingomyelin (L/S) ratios and phosphatidylglycerol as percentage of total phospholipids measured (\% $\mathrm{PG}$ ) were always found to be similar to control values. Phosphatidylcholine as percentage of total phospholipids (\%PC) and SP-A and SP-B protein and mRNA levels were mostly normal in $\mathrm{CDH}$ during early gestation, whereas both normal and decreased levels were reported for late gestation. SP-C protein and mRNA levels in CDH were reported unchanged in most studies. $\uparrow$, increased; $\downarrow$, decreased; =, no difference; E, embryonic day; BAL, bronchoalveolar lavage; AF, amniotic fluid; RT-PCR, reverse-transcriptase polymerase chain reaction; Species: human, references 17-20; lamb (surgical-created $\mathrm{CDH}$ ), references 23, 26, 28, 32, 36; rat (nitrofen-induced $\mathrm{CDH}$ ), references 24, 25, 27, 29, 31, 33-35, 37, 38; mouse (nitrofen-induced $\mathrm{CDH}$ ), reference 30. 
the mid-pseudoglandular stage of lung development, E18 to late pseudoglandular, E20 to late canalicular, and E22 to the saccular stage of lung development. Animal experiments were performed in accordance with the guidelines of the animal research committee of the Academic Medical Center of the University of Amsterdam.

Tissue preparation. At E15-E22, embryos were delivered by cesarean section and their thoraxes were fixed in $4 \%$ phosphate-buffered formaldehyde ( $\mathrm{wt} / \mathrm{vol})\left(4^{\circ} \mathrm{C}, 16-18 \mathrm{~h}\right)$, dehydrated in a graded series of ethanol solutions, cleared with 1-butanol, and embedded in Paraplast Plus (Monoject, Kildare, Ireland). Seven-micrometer frontal sections were cut and mounted onto RNAse-free 3-aminopropyltriethoxysilane(Sigma Chemical Co., St. Louis, MO, U.S.A.) coated slides. From each embryo, the entire thorax was embedded and cut, and only embryos that had a visible diaphragmatic hernia and lung hypoplasia were used for the study.

In situ hybridization. Plasmids containing mouse SP-A and SP-C (both in pGEM3Z) and SP-B (in pBS-SKII) cDNA were obtained from Dr. J.A. Whitsett (Division of Pulmonary Biology, Children's Hospital Medical Center, Cincinnati, OH, U.S.A.) $(43-45)$. $\left[\alpha^{-35} \mathrm{~S}\right] \mathrm{dCTP}-$ labeled antisense probes for SP-A, -B, and -C were generated with $\mathrm{T} 7$ polymerase, after linearization of the plasmids with ApaLI, EcoRI, and HindIII, respectively. The hybridization conditions were as described elsewhere (46). Exposure time to nuclear autoradiographic emulsion (Ilford Nuclear Research Emulsion G-5; Ilford, Cheshire, UK) was $14 \mathrm{~d}$ for SP-A and $7 \mathrm{~d}$ for SP-B and -C. The development time was 4 min. After developing, the sections were dehydrated in a graded series of ethanol and xylol, and mounted in Malinol (Chroma-Gesellshaft, Schmidt Gmbh $+\mathrm{Co}$, Köngen, Germany).

Image acquisition and analysis. For image acquisition, a Photometrics cooled-CCD camera (Tucson, AZ, U.S.A.; 12-bit dynamic range; $1317 \times 1035$ pixels), attached to an Axioplan microscope (Carl Zeiss, Oberkochen, Germany) equipped with a $5 \times$ objective (N.A.: 0.15 ), a stabilized power supply, and an infrared-blocking filter was used. The low-power objective was used to assure the sampling of several respiratory acini in an image, representing $2.5 \mathrm{~mm}^{2}$ of the lung section. Digital images from the in situ hybridization procedure were recorded using white light (40). The digital transmission images were converted to OD images by calculating the negative logarithm of the transmission image divided by an image of the light source $\left(\mathrm{OD}=-{ }^{10} \log \left(\mathrm{I} / \mathrm{I}_{0}\right)\right.$ for each pixel). This conversion implicitly corrects background shading.

The OD images were analyzed using the public domain image analysis program from the National Institutes of Health-Image (available at rsb.info.nih.gov/nih-image; version 1.61). The areas to be measured were marked by an interactive density slice, which identifies structures based on a selected lower and upper density value. Tissue background was defined as nonstaining tissue such as esophagus or cartilage tissue. Signal was defined as specific positive staining due to hybridization (signal in the bronchiolar and alveolar epithelium) $(40,46)$. The definitive signal value, expressed as mean $\mathrm{OD}$, is obtained by subtracting the mean tissue background density from the mean signal density $(40,46)$. The positive signal is plotted as mean OD ( \pm SEM) per group and age. The volume fraction of SP mRNA-expressing cells (\% Area) was calculated from the area of positive staining cells in the section and the total lung area (excluding airspaces). All lung measurements were carried out three times with a randomized series of images. No differences were observed between the three measurements and, therefore, a mean value per lung was calculated.

Immunohistochemistry. All antibodies were obtained from Dr. J.A. Whitsett (Division of Pulmonary Biology, Children's Hospital Medical Center, Cincinnati, OH, U.S.A.). A guinea pig polyclonal antibody against rat SP-A, a rabbit polyclonal antibody against mature bovine SP-B (R28031), and a rabbit polyclonal antibody against human proSP-C (R68514) were applied at a dilution of 1:300, 1:2000, and 1:5000, respectively, to $7 \mu \mathrm{m}$ deparaffinized sections $(47,48)$. For SP-A, a Vectastain $\mathrm{ABC}$ Peroxidase kit and for SP-B and proSP-C a Vector Elite $\mathrm{ABC}-\mathrm{DAB}$ kit (Vector Laboratories, Burlingame, CA, U.S.A.) were used to detect antigen-antibody complexes (48). The enzymatic reaction product was enhanced with nickel/ cobalt to produce a black precipitate. Sections were counterstained with nuclear fast red. For each different protein, slides were handled in similar ways concerning the concentration of the antibody and the times for incubation and detection. Analysis of the pattern and intensity of protein staining was done blindly by two persons.

Statistical analysis. Variations in staining intensity due to the different in situ hybridization sessions were removed by subtracting the session effects calculated from the logtransformed data with the general linear model ANOVA without interaction (SPSS version 10.0.7; SPSS Inc., Chicago, IL, U.S.A.). Differences between groups (control versus $\mathrm{CDH}$ ) and age [two animals per group per age for E15, E18, E20, and E22 (control) and three animals per group for E22 (CDH)] and between ipsilateral (hernia) and contralateral (no hernia) lung and age were tested with a two-way ANOVA.

\section{RESULTS}

In situ hybridization. SP-A and -B mRNA are normally expressed in both bronchiolar and alveolar epithelial cells, whereas SP-C mRNA is only expressed in alveolar epithelial cells. The patterns of mRNA expression for SP-A, -B, and -C did not differ between control (Figs. 1-3, panels $A, C, E$ ) and $\mathrm{CDH}$ (Figs. 1-3, panels $B, D, F$ ) lungs at the gestational ages analyzed. SP-A and -B mRNA expression started at a very low level at E15 (not shown). SP-A mRNA was expressed in alveolar epithelial cells and from E20 onwards also at low levels in bronchiolar epithelial cells (Figs. 1-3, panels $A$ and $B$ ). SP-B mRNA was expressed in alveolar epithelial cells and from E20 onwards as well at high levels in bronchiolar epithelial cells (Figs. 1-3, panels $C$ and $D$ ). At E15, SP-C mRNA was already expressed at a high level in pulmonary epithelial cells (not shown). At later stages, SP-C mRNA was expressed only in alveolar (distal) epithelial cells (Figs. 1-3, panels $E$ and $F)$. No differences in the expression patterns of the respective SP mRNAs were observed between the ipsilateral and the contralateral side of CDH lungs (not shown). Figure 3 also 

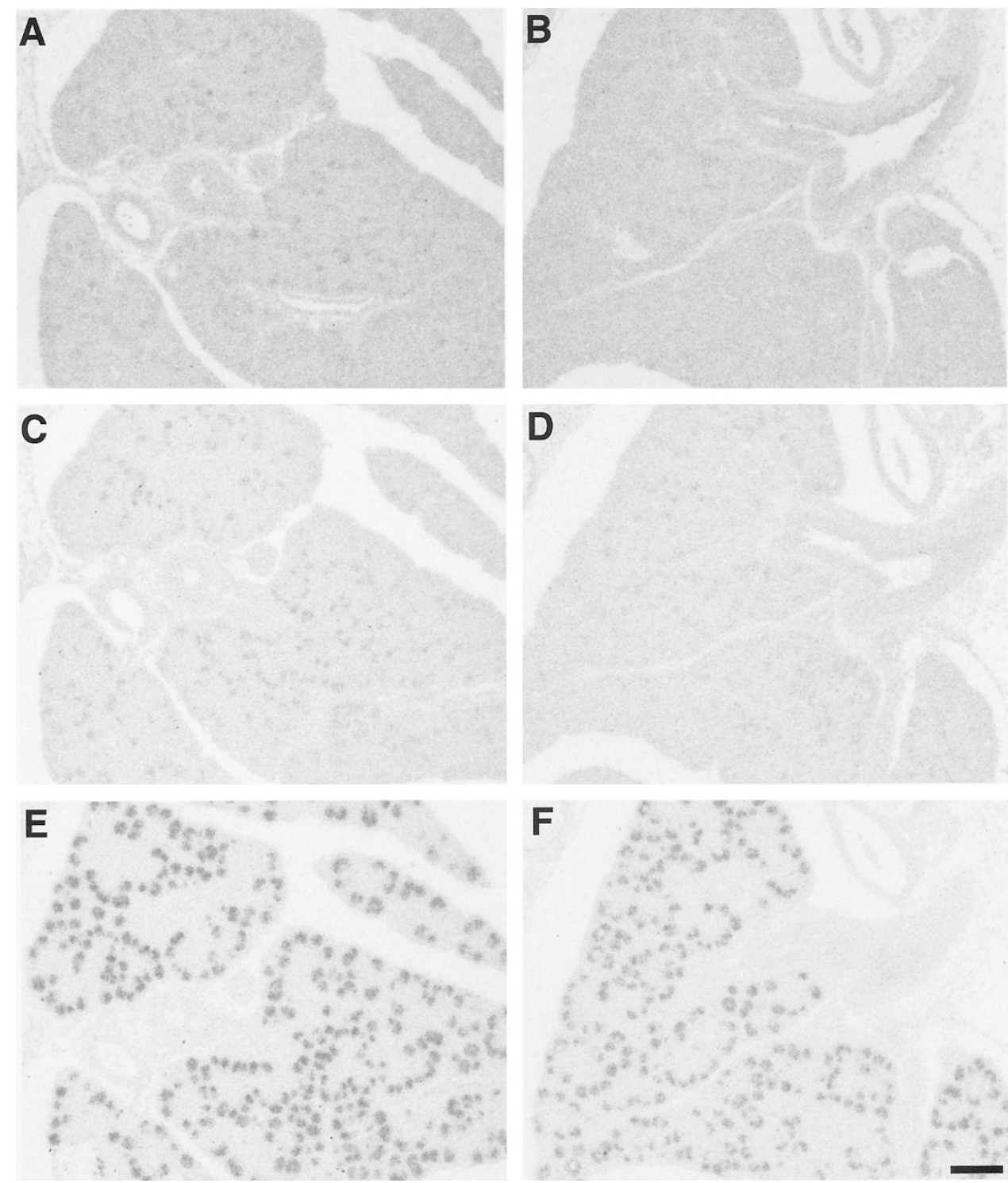

Figure 1. Expression of SP-A $(A, B)$, SP-B $(C, D)$, and SP-C $(E, F)$ mRNA in serial sections of lungs of E18 control $(A, C, E)$ and $\mathrm{CDH}(B, D, F)$ rat fetuses. SP-A, $-\mathrm{B}$, and $-\mathrm{C}$ mRNA were expressed in the alveolar epithelial cells of both control and CDH lungs. Bar $=200 \mu \mathrm{m}$.

revealed that at $\mathrm{E} 22$ the morphology of the $\mathrm{CDH}$ lungs differed substantially from the control lungs. Although pictures were taken at the same magnification, $\mathrm{CDH}$ lungs (Fig. 3, $B, D, F$ ) were smaller than control lungs (Fig. 3, $A, C, E$ ) and contained only a few visible airspaces, in contrast to the control lungs where airspaces were abundant at this gestational age. Note also that the airspaces in $\mathrm{CDH}$ lungs (Fig. 3, $B, D, F$ ) are poorly expanded.

Quantification of the in situ hybridization results. The cellular concentration (mean OD) of SP-A, -B, and -C mRNA in control and $\mathrm{CDH}$ lungs increased with advancing gestational age (Fig. 4). All SP mRNAs increased in cellular concentration (Fig. 4, $A, C, E$ ), whereas the volume fraction of cells (\% Area) expressing the respective mRNAs also increased (Fig. 4, $B, D$, $F)$. Nevertheless, the behavior of the SP mRNAs differed slightly from each other. SP-C mRNA levels increased early (Fig. $4 E$ ) and before SP-A and SP-B mRNA levels (Fig. 4, $A$ and $C$ ). The mean OD of SP-A and SP-B mRNA was similar between control and CDH lungs at all ages (Fig. 4, $A$ and $C$ ). The mean OD of SP-C mRNA was similar between control and $\mathrm{CDH}$ lungs between E15 and E20, and higher in CDH lungs at E22 (Fig. $4 E$, group · age effect, $p=0.007$ ). For SP-A, -B, and -C mRNA, the volume fraction of mRNA-expressing cells (\% Area) was similar between $\mathrm{CDH}$ and control lungs until E20 and was higher in CDH lungs at E22 (Fig. 4, $B, D, F$; group * age effect, $p=0.009, p=0.014, p=0.002$, respectively). These results show that the cellular concentration (mean $\mathrm{OD})$ of SP mRNA in the $\mathrm{CDH}$ lungs is equal to the concentration found in a similar cell in control lungs for SP-A and -B. For SP-C mRNA, there is increased expression in $\mathrm{CDH}$ lungs at the end of gestation (E22). Furthermore, the volume fraction of cells (\% Area) expressing SP mRNA as a percentage of total lung tissue (excluding airspaces) is higher near term in $\mathrm{CDH}$ lungs. In summary, these results indicate that there is no deficiency of SP-A, -B, or - $\mathrm{C}$ mRNA in $\mathrm{CDH}$ lungs. 

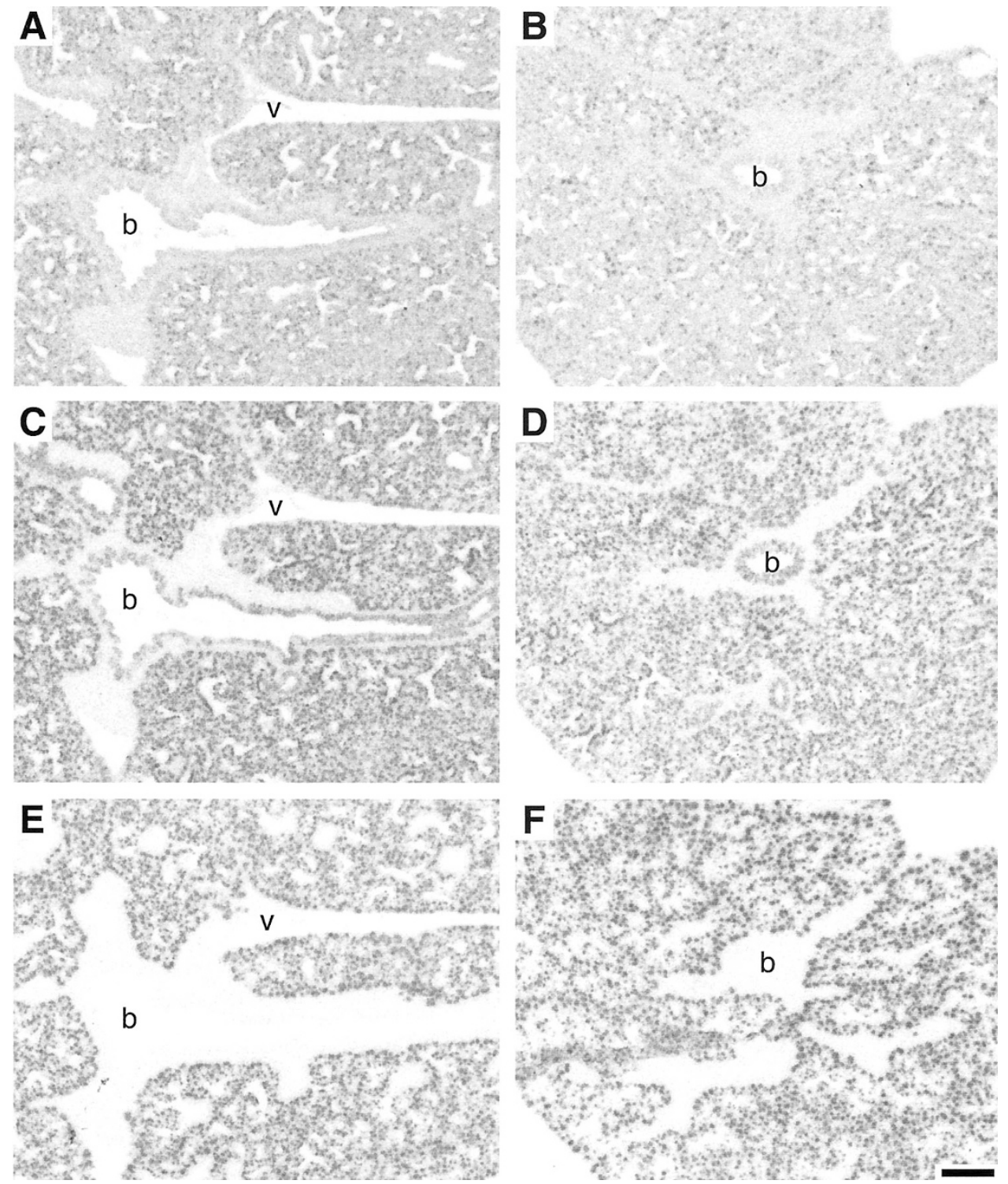

Figure 2. Expression of SP-A $(A, B)$, SP-B $(C, D)$, and SP-C $(E, F)$ mRNA in serial sections of lungs of E20 control $(A, C, E)$ and $C D H(B, D, F)$ rat fetuses. In both control and $\mathrm{CDH}$ lungs, the three mRNAs were detected in alveolar epithelial cells. At this stage of development, SP-B mRNA was also detected in bronchiolar epithelial cells of both control and CDH lungs. Weak SP-A and no SP-C mRNA was detected in bronchiolar epithelial cells. $v$, blood vessel; $b$, bronchiole. Bar $=200 \mu \mathrm{m}$.

Because the lung at the side of the diaphragmatic defect (ipsilateral lung) was always more hypoplastic than the contralateral lung, we investigated the cellular concentration (mean OD) of SP mRNA (Fig. 5, $A, C, E$ ) and the volume fraction (\% Area) of SP-expressing cells (Fig. 5, B, D, F) between the ipsilateral and contralateral side of a CDH lung. In both the ipsilateral and contralateral $\mathrm{CDH}$ lung, the mean OD of SP-A, -B, and -C mRNA increased with gestational age and no differences were observed between the two lungs (Fig. 5, $A$, $C, E$ ). Similarly, the \% Area of SP-expressing cells increased with gestational age and no differences were found between the ipsilateral and contralateral side of a $\mathrm{CDH}$ lung (Fig. 5, $B, D$, F).

Immunohistochemistry. SP-A (Fig. 6) and SP-B (Fig. 7) proteins were detected in the bronchiolar and alveolar epithelial cells of both control and CDH lungs. Expression of both proteins increased in control and $\mathrm{CDH}$ fetuses with advancing gestational age and no differences in expression pattern or staining intensity were observed between the control (Figs. 6 and 7, $A$ and $C$ ) and CDH (Figs. 6 and 7, $B$ and $D$ ) lungs at E20 (Figs. 6 and 7, $A$ and $B$ ) or E22 (Figs. 6 and 7, $C$ and $D$ ). No differences in the pattern or intensity of SP-A or -B staining were observed between the ipsilateral (hernia) and contralateral (no hernia) side of E22 CDH lungs (not shown). Clear proSP-C staining was observed in control (Fig. 8, $A$ and $C$ ) and $\mathrm{CDH}$ (Fig. 8, $B$ and $D$ ) lungs at E20, where it appeared higher in $\mathrm{CDH}$ (Fig. $8 B$ ) lungs than in control (Fig. $8 A$ ) lungs. However, at E22 (Fig. 8, $C$ and $D$ ) this difference could no longer be observed. In both control and CDH lungs, proSP-C was only detected in alveolar epithelial cells. At E22, there was no difference in intensity or pattern of proSP-C staining between the ipsilateral and the contralateral side of $\mathrm{CDH}$ lungs (not 

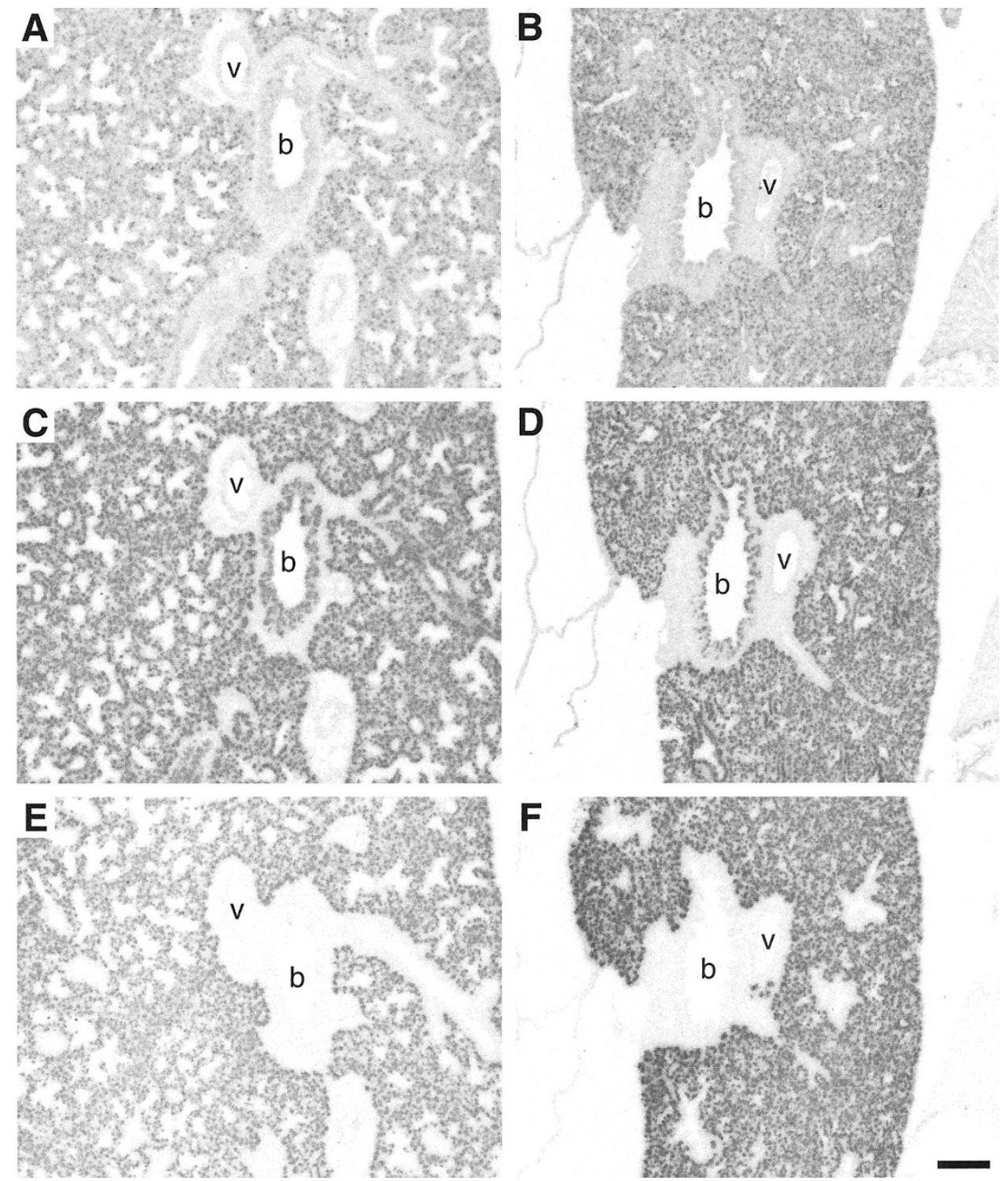

Figure 3. Expression of SP-A $(A, B)$, SP-B $(C, D)$, and SP-C $(E, F)$ mRNA in serial sections of lungs of E22 control $(A, C, E)$ and $\mathrm{CDH}(B, D, F)$ rat fetuses. In both control and $\mathrm{CDH}$ lungs, SP-A, - B, and -C mRNA were detected in alveolar epithelial cells. SP-A and -B mRNA were also expressed in bronchiolar epithelial cells, whereas SP-C mRNA was never detected in these cells. $v$, blood vessel; $b$, bronchiole. Bar $=200 \mu \mathrm{m}$.

shown). These results show that the respective mRNAs are properly translated into protein and therefore indicate that lungs of nitrofen-induced $\mathrm{CDH}$ rat fetuses do not have a primary deficiency of surfactant proteins.

\section{DISCUSSION}

$\mathrm{CDH}$ is characterized by a diaphragmatic defect, pulmonary hypoplasia, and pulmonary hypertension. In the $\mathrm{CDH}$ neonate, pulmonary hypoplasia is often complicated by respiratory failure, low lung compliance, increased inspiratory resistance, and hyaline membrane formation (5). Based on inconsistent results from human and experimental animal studies with regard to the use of surfactant (prophylactic or rescue therapy) in $\mathrm{CDH}$, we tested the hypothesis that $\mathrm{CDH}$ lungs are surfactant-deficient, which could explain in part the respiratory failure and difficulties in treating $\mathrm{CDH}$ infants. In this study, we showed that mRNA and protein expression of SP-A, -B and -C, in both control and $\mathrm{CDH}$ lungs, increased with advancing gestational age and no differences were present in the cellular concentration (mean OD) of SP-A, -B, and -C mRNA between control and $\mathrm{CDH}$ lungs except for a higher concentration of SP-C mRNA at term (E22) in CDH lungs. The volume fraction of SP mRNA-expressing cells (\% Area) similarly increased with gestational age in control and $\mathrm{CDH}$ lungs and near term more SP mRNA-expressing cells were found in $\mathrm{CDH}$ lungs than in controls. This increased volume fraction of SP mRNAexpressing cells is in agreement with the increased number of surfactant-producing type II cells in CDH lungs. Using electron microscopy, it was shown that $\mathrm{CDH}$ lungs from fetal lambs $(36,49)$ and rats $(50)$ had increased numbers of pulmonary type II cells, and more recently it was shown that those cells exhibit normal type II cell maturation (35). Furthermore, no differences were found in the cellular concentration of the SP mRNAs or in the volume fraction of SP mRNA-expressing 

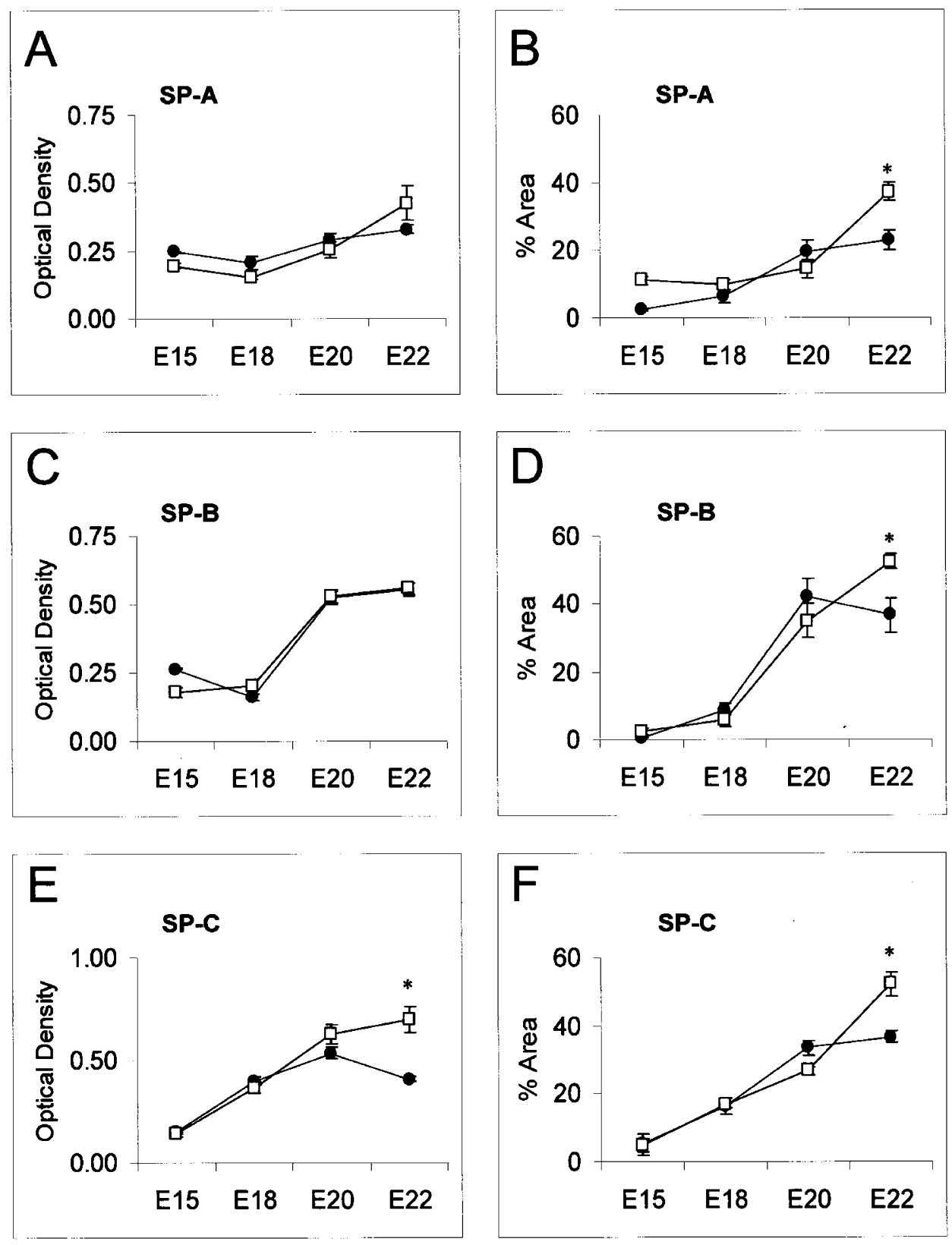

Figure 4. Quantification of the in situ hybridization signals for SP-A $(A, B)$, SP-B $(C, D)$, and SP-C $(E, F)$ mRNA in control (solid circles) and CDH (open squares) lungs. Mean OD was measured as described in the "Methods" section and indicates the cellular concentration of SP mRNA ( $A$, $C, E$ ). The volume fraction of cells expressing SP mRNA is given as a percentage (\% Area) of the total lung tissue measured (both staining and nonstaining lung tissue, airspaces excluded) $(B, D, F)$. Both parameters increased with age in control and CDH lungs. At E22, the mean OD of SP-C mRNA and the \% Area of cells expressing SP-A, -B, and -C mRNA was higher in CDH than in control lungs (significant group $\cdot$ age effect, $p=0.007,0.009,0.014$, and 0.002 , respectively).

cells between the ipsilateral (hernia) and contralateral (no hernia) side of CDH lungs. This study therefore demonstrates that there is no primary deficiency of surfactant proteins in the nitrofen-induced $\mathrm{CDH}$ rat model. It is, however, possible that the total amount of surfactant protein is less because $\mathrm{CDH}$ animals have smaller lungs.

Data on the surfactant status of $\mathrm{CDH}$ humans and experimental animals are not consistent. Both normal and decreased levels for DSPC and SP-A protein and mRNA were reported in $\mathrm{CDH}$ lungs. SP-C protein and mRNA levels were more often reported normal than decreased, whereas SP-B protein levels were often decreased, however, normal mRNA levels were also found in $\mathrm{CDH}$ compared with control lungs (Table 1). Despite animal data, neither a primary surfactant deficiency nor a beneficial effect of surfactant replacement therapy has been proven in human CDH infants (18, 51-53). These apparent discrepancies and the variably high mortality rate of $\mathrm{CDH}$ infants led us to investigate the surfactant protein status in the nitrofen-induced $\mathrm{CDH}$ rat model using a novel in situ hybridization technique.

The key finding in this study was that with quantitative in situ hybridization we showed that in the same sample, the expression pattern and the cellular concentration of SP-A and SP-B mRNA did not differ between CDH and control lungs, 

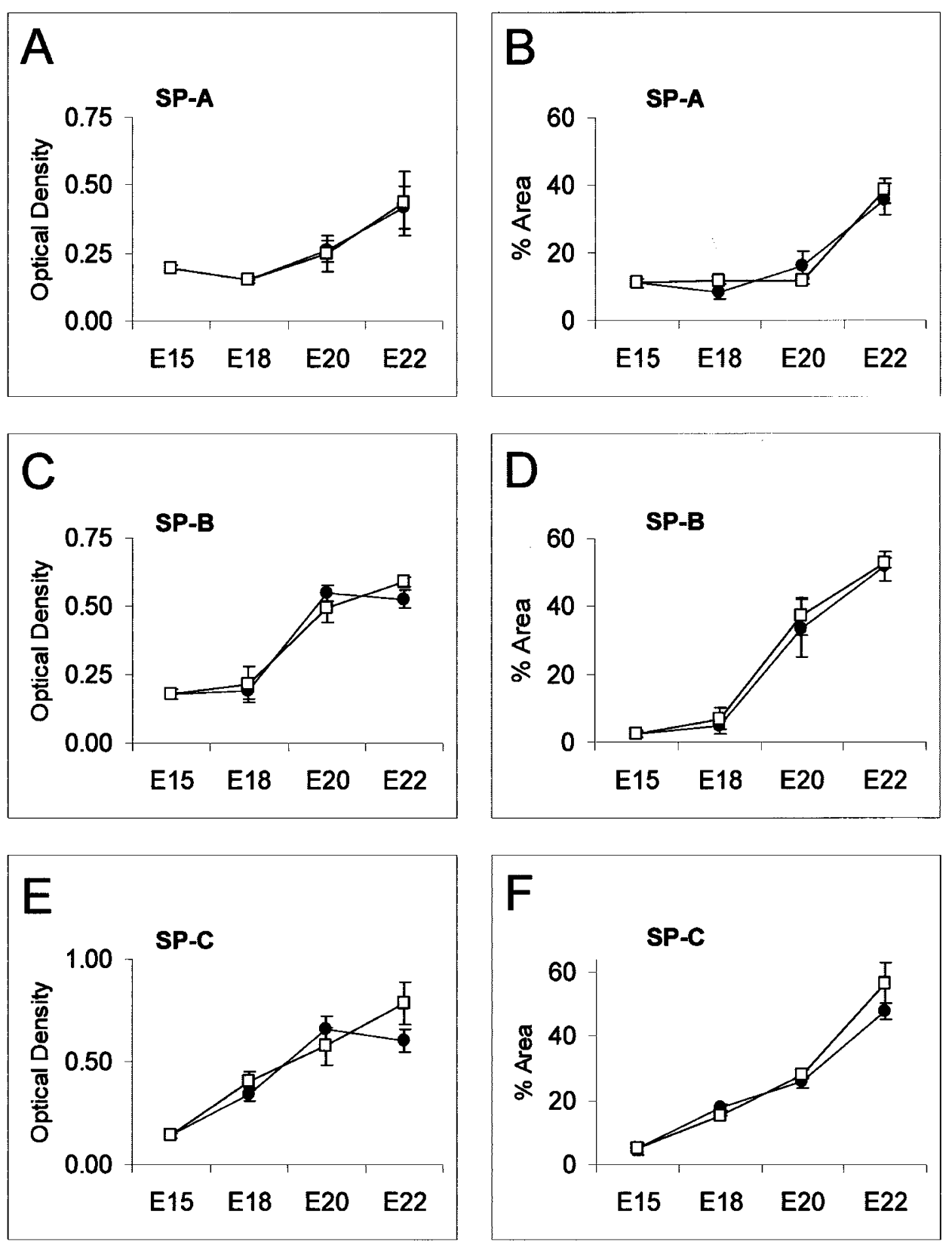

Figure 5. Quantification of the in situ hybridization signals for SP-A $(A, B)$, SP-B $(C, D)$ and SP-C $(E, F)$ mRNA in the contralateral (no hernia, solid circles) and ipsilateral (hernia, open squares) side of CDH lungs. Mean OD was measured as described in the "Methods" section and indicates the cellular concentration of SP mRNA $(A, C, E)$. The volume fraction of cells expressing SP mRNA is given as a percentage (\% Area) of the total lung tissue measured (both staining and nonstaining lung tissue, airspaces excluded) $(B, D, F)$. Both parameters increased with advancing gestational age and no differences were found between the ipsilateral and contralateral side of $\mathrm{CDH}$ lungs.

whereas the expression pattern of SP-C mRNA was similar, but the level of expression was higher in $\mathrm{CDH}$ than in control lungs at the end of gestation (E22). The quantitative in situ hybridization technique is an adequate approach to measure differences in mRNA level in the context of changing tissue architecture or a changing expression pattern of a gene $(40,46$, 54). These simultaneous observations cannot be made with techniques that require tissue homogenization, such as Northern blot analysis. The advantage of quantitative in situ hybridization is that it is possible to locate a positive staining cell in the original tissue and that at the same time it is possible to measure mRNA expression levels per cell. Our study was carried out in the laboratory where the quantitative in situ hybridization technique was developed and extensively validated with Northern blot analysis $(40,46)$. Jonker et al. (40) showed that the integrated OD (mean OD) of silver grains produced in liver and intestinal sections by the in situ hybridization procedure using ${ }^{35} \mathrm{~S}$-labeled riboprobes (i.e. positive signal) is directly proportional to the signal obtained by quantitative Northern blot analysis and, more recently, Moorman et al. (55) used the very same technique to distinguish cardiac specific mRNA expression levels in different parts of the developing heart. In further support, the line of increase of SP mRNA levels with advancing gestational age in control rat 

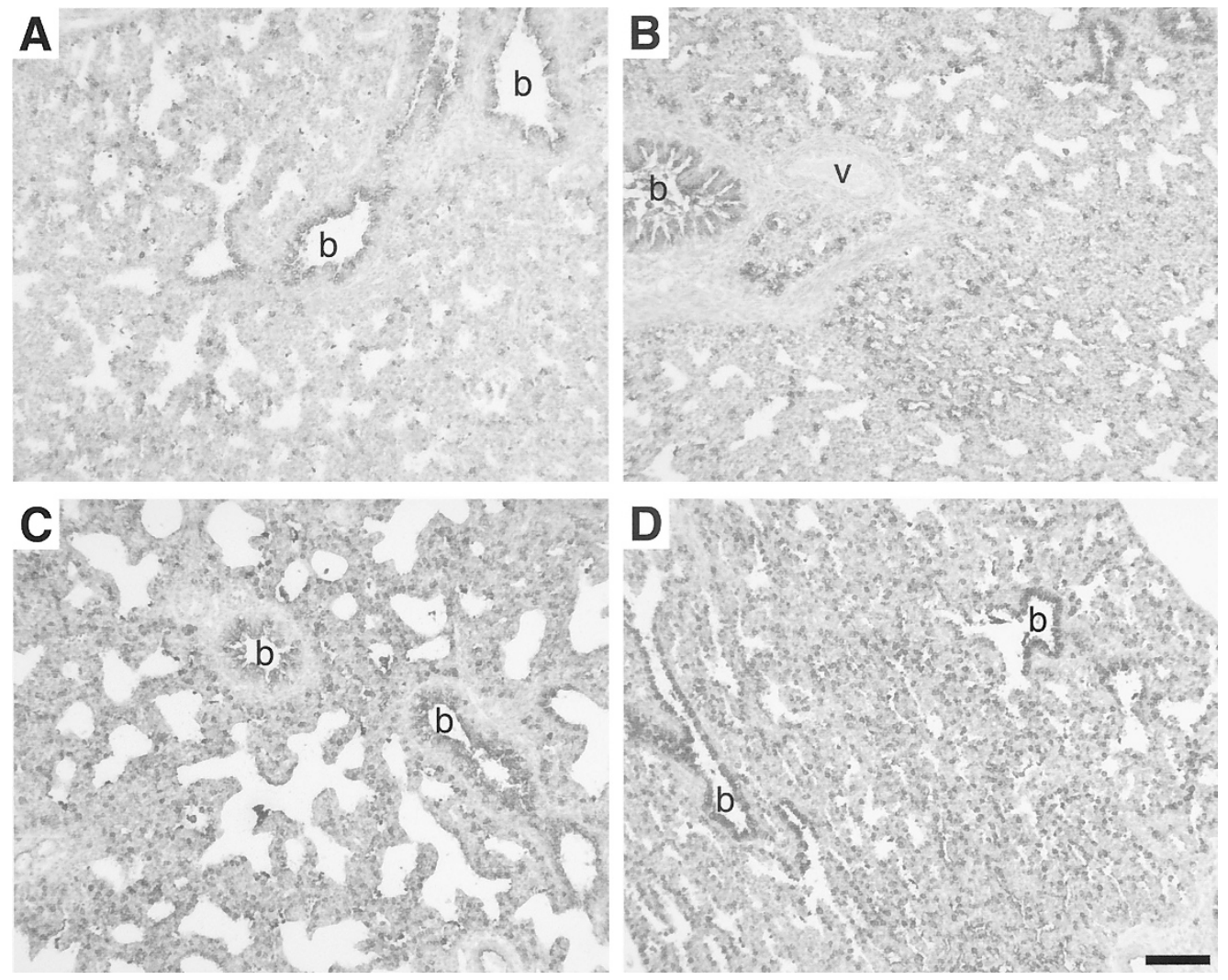

Figure 6. Immunohistochemical staining for SP-A at E20 $(A, B)$ and E22 $(C, D)$ in control $(A, C)$ and $\mathrm{CDH}(B, D)$ rat lungs. SP-A was expressed in alveolar and bronchiolar epithelial cells of both control and CDH lungs. Note the difference in morphology between control and CDH lungs at E22. $v$, blood vessel; $b$, bronchiole. Bar $=100 \mu \mathrm{m}$.

lungs in our study is in agreement with published data from Schellhase et al. (56). These authors used Northern blot analysis to show that in control fetal rat lungs, SP-A and SP-B mRNA levels are very low before E17 and markedly increase from E18 to E19 and further increase till E21 (term = E22). Similar to our study (term = E23), they also showed that SP-C mRNA levels are already high at E17, increase dramatically toward E19, and further increase toward adult levels by E21 (56).

We think that the measurement of mRNA concentration in the cell of interest (via in situ hybridization), as opposed to the measurement of mRNA levels per tissue volume (via e.g. Northern blot analysis) can account for the observed differences between our study and that of Thébaud et al. (38). Using Northern blot analysis, these latter authors found normal levels of SP-B and decreased levels of SP-A and SP-C mRNA in nitrofen-induced $\mathrm{CDH}$ rats at E21 (term $=\mathrm{E} 22)$. Northern blot analysis includes all cells, including non-SP-producing cells, in the tissue base, whereas the in situ hybridization approach only includes SP-producing cells. In view of the altered morphology of $\mathrm{CDH}$ lungs, the contribution of non-SP-producing cells (e.g. fibroblasts) is larger in hypoplastic CDH lungs than in control lungs, especially near term as was recently shown by Guilbert et al. (35). In this case, the key advantage of quantitative in situ hybridization is the possibility to avoid the contribution of fibroblast and other nonsurfactant-producing cells and selectively measure SP mRNA levels in pulmonary epithelial cells.
From the study by Guilbert et al. (35) a similar conclusion can be drawn. These authors used RNA protection assay to measure the different levels of SP mRNA in nitrofen-induced $\mathrm{CDH}$ rats and showed normal SP-A, -B, and -C mRNA levels in contralateral $\mathrm{CDH}$ lungs compared with control lungs at any time and only decreased levels of SP-B and -C mRNA in ipsilateral CDH lungs at E21 (term = E22), which is the time when morphologic abnormalities (increased ratio of mesenchyme to epithelium) in CDH lungs are most apparent $(35,57)$. However, they also showed that in situ hybridization for SP-C mRNA did not show any difference between control and CDH lungs at E21, which supports the results presented in our study.

Using immunohistochemistry, we found no differences in the protein staining pattern or intensity of SP-A, -B, and proSP-C, indicating that the respective mRNAs are properly translated into proteins. The surfactant protein antibodies used in this study were previously shown to be highly specific (16, 48). Our immunohistochemistry results are in line with results from Zhou et al. (16), who found no differences in the expression of SP-A, -B, and proSP-C proteins in various cases of human lung hypoplasia, including $\mathrm{CDH}$.

DSPC is as important for the function of surfactant as the surfactant proteins. Secreted surfactant is composed of $90 \%$ lipids, 9\% proteins, and 1\% carbohydrate (15). Experimental animal data support both decreased and normal levels of DSPC in $\mathrm{CDH}$ (Table 1). Interestingly, a recently published paper showed that DSPC synthesis in human CDH infants on venti- 

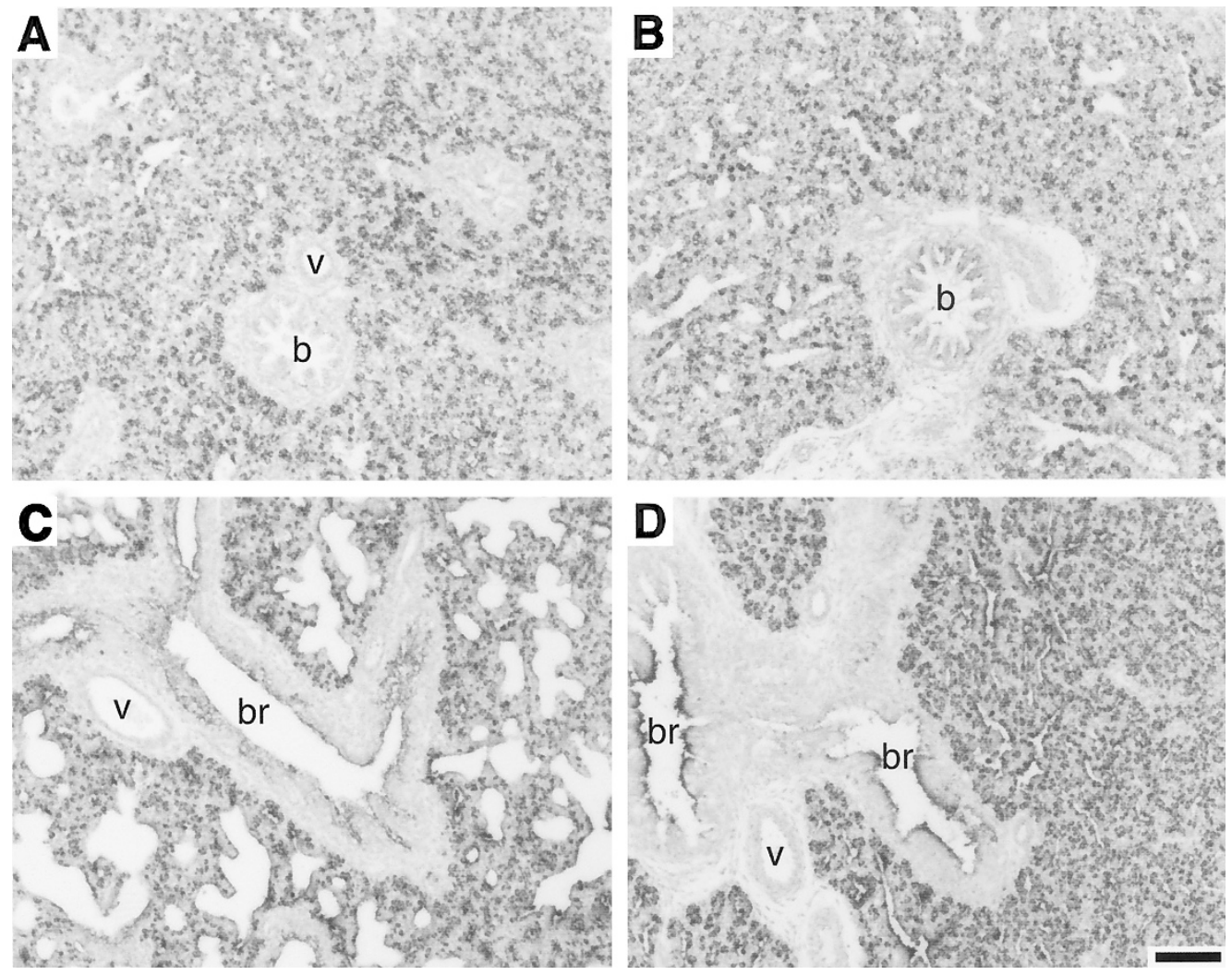

Figure 7. Immunohistochemical staining for SP-B at E20 $(A, B)$ and $\mathrm{E} 22(C, D)$ in control $(A, C)$ and $\mathrm{CDH}(B, D)$ rat lungs. SP-B was expressed in alveolar epithelial cells of both control and CDH lungs. Some staining is also detected in E20 bronchiolar epithelial cells. At E22, SP-B was expressed at high levels in alveolar and bronchiolar epithelial cells of both control and CDH lungs. $v$, blood vessel; $b$, bronchiole; $b r$, bronchus. Bar $=100 \mu \mathrm{m}$.
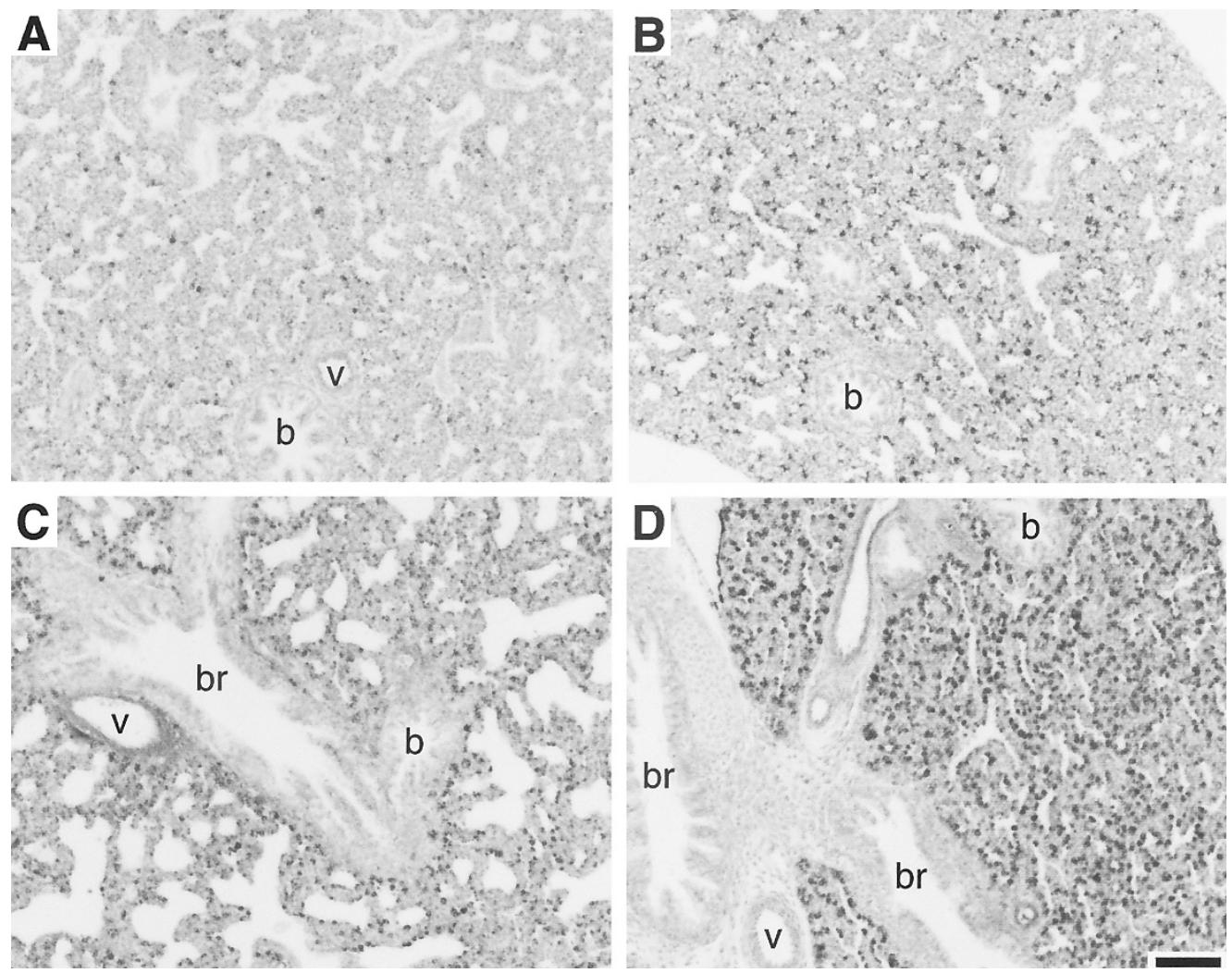

Figure 8. Immunohistochemical staining for proSP-C at E20 $(A, B)$ and E22 $(C, D)$ in control $(A, C)$ and $\mathrm{CDH}(B, D)$ rat lungs. ProSP-C was expressed in alveolar epithelial cells of both control and CDH lungs. ProSP-C was never observed in bronchiolar epithelial cells. $v$, blood vessel; $b$, bronchiole; $b r$, bronchus. Bar $=100 \mu \mathrm{m}$. 
lation was not different from control infants (no respiratory disease) on ventilation (52). Similarly, our group showed that $\mathrm{CDH}$ infants had a normal \% DSPC in their BAL fluid (18) and more recently that $\mathrm{CDH}$ infants on ECMO are not surfactantdeficient when compared with infants on ECMO who suffer from meconium aspiration or with ventilated $\mathrm{CDH}$ infants (51). These results indicate that a primary surfactant deficiency is not likely in $\mathrm{CDH}$ infants.

That impaired lung development and subsequent respiratory distress can develop without a primary SP deficiency was also shown in an entirely different experimental model (58). Fetal rats with oligohydramnios suffer from a marked pulmonary hypoplasia; in humans, this often leads to respiratory distress at birth. However, despite the profound pulmonary hypoplasia, normal levels of saturated PC (phosphatidyl choline), SP-A, SP-B, and SP-C mRNA were found (58).

Although we did not find a primary deficiency in surfactant proteins, it is still possible that a secondary deficiency develops postnatally due to the nature of the disease with morphologically immature lungs and/or postnatal ventilation strategies. If (secondary) surfactant deficiency were a major component in the clinical course of $\mathrm{CDH}$, one would expect beneficial results from prenatal corticosteroid injections or surfactant replacement therapy, treatments that have dramatically reduced the mortality rate in surfactant-deficient RDS infants. Although animal CDH models showed an improvement of lung morphology after prenatal corticosteroid treatment (59-62), unfortunately, no human randomized controlled trials for the use of surfactant or prenatal corticosteroids in $\mathrm{CDH}$ have been carried out and only anecdotal data are available (63-65), which, as recently reviewed (53), do not support a primary surfactant deficiency in $\mathrm{CDH}$.

\section{CONCLUSION}

In conclusion, this study showed that there is no primary deficiency of surfactant proteins in the nitrofen-induced rat model of $\mathrm{CDH}$. If extrapolation to the human situation is allowed, it is possible that the respiratory failure in $\mathrm{CDH}$ infants does not necessarily result from biochemically immature lungs but rather from morphologic immaturity and perhaps vascular abnormalities. Above all, a significant contribution to respiratory insufficiency in $\mathrm{CDH}$ is iatrogenic, as suggested in recent papers and a secondary surfactant deficiency cannot be excluded under these circumstances (21).

Acknowledgments. The authors thank Ms. Paula Blair for technical assistance with immunohistochemistry for SP-B and proSP-C.

\section{REFERENCES}

1. Torfs CP, Curry CJ, Bateson TF, Honore LH 1992 A population-based study of congenital diaphragmatic hernia. Teratology 46:555-565

2. Benjamin DR, Juul S, Siebert JR 1988 Congenital posterolateral diaphragmatic hernia: associated malformations. J Pediatr Surg 23:899-903

3. Fauza DO, Wilson JM 1994 Congenital diaphragmatic hernia and associated anomalies: their incidence, identification, and impact on prognosis. J Pediatr Surg 29:11131117

4. Tibboel D, Gaag AV 1996 Etiologic and genetic factors in congenital diaphragmatic hernia. Clin Perinatol 23:689-699
5. Thébaud B, Mercier JC, Dinh-Xuan AT 1998 Congenital diaphragmatic hernia. A cause of persistent pulmonary hypertension of the newborn which lacks an effective therapy. Biol Neonate 74:323-336

6. Kays DW, Langham Jr MR, Ledbetter DJ, Talbert JL 1999 Detrimental effects of standard medical therapy in congenital diaphragmatic hernia. Ann Surg 230:340-348

7. Boloker J, Bateman DA, Wung JT, Stolar CJ 2002 Congenital diaphragmatic hernia in 120 infants treated consecutively with permissive hypercapnea/spontaneous respiration/elective repair. J Pediatr Surg 37:357-366

8. Beresford MW, Shaw NJ 2000 Outcome of congenital diaphragmatic hernia. Pediatr Pulmonol 30:249-256

9. IJsselstijn H, Tibboel D 1998 The lungs in congenital diaphragmatic hernia: do we understand? Pediatr Pulmonol 26:204-218

10. van Tuyl M, Hösgor M, Tibboel D 2001 Tracheal ligation and corticosteroids in congenital diaphragmatic hernia: for better for worse? Pediatr Res 50:441-444

11. 1995 Effect of corticosteroids for fetal maturation on perinatal outcomes. NIH Consensus Development Panel on the Effect of Corticosteroids for Fetal Maturation on Perinatal Outcomes JAMA 273:413-418

12. Bolt RJ, van Weissenbruch MM, Lafeber HN, Delemarre-van de Waal HA 2001 Glucocorticoids and lung development in the fetus and preterm infant. Pediatr Pulmonol 32:76-91

13. Soll RF, Morley CJ 2001 Prophylactic versus selective use of surfactant in preventing morbidity and mortality in preterm infants. Cochrane Database Syst Rev 2:CD000510

14. Floros J, Kala P 1998 Surfactant proteins: molecular genetics of neonatal pulmonary diseases. Annu Rev Physiol 60:365-384

15. Haagsman HP, van Golde LM 1991 Synthesis and assembly of lung surfactant. Annu Rev Physiol 53:441-464

16. Zhou H, Morotti RA, Profitt SA, Langston C, Wert SE, Whitsett JA, Greco MA 2001 Expression of thyroid transcription factor-1, surfactant proteins, type I cell-associated antigen, and Clara cell secretory protein in pulmonary hypoplasia. Pediatr Dev Pathol $4: 364-371$

17. Sullivan KM, Hawgood S, Flake AW, Harrison MR, Adzick NS 1994 Amniotic fluid phospholipid analysis in the fetus with congenital diaphragmatic hernia. J Pediatr Surg 29:1020-1023

18. IJsselstijn H, Zimmermann LJ, Bunt JE, de Jongste JC, Tibboel D 1998 Prospective evaluation of surfactant composition in bronchoalveolar lavage fluid of infants with congenital diaphragmatic hernia and of age-matched controls. Crit Care Med 26:573580

19. Moya FR, Thomas VL, Romaguera J, Mysore MR, Maberry M, Bernard A, Freund M 1995 Fetal lung maturation in congenital diaphragmatic hernia. Am J Obstet Gynecol 173:1401-1405

20. Asabe K, Tsuji K, Handa N, Kurosaka N, Kajiwara M 1997 Immunohistochemica distribution of surfactant apoprotein-A in congenital diaphragmatic hernia. J Pediatr Surg 32:667-672

21. Sakurai Y, Azarow K, Cutz E, Messineo A, Pearl R, Bohn D 1999 Pulmonary barotrauma in congenital diaphragmatic hernia: a clinicopathological correlation. J Pediatr Surg 34:1813-1817

22. Wilcox DT, Irish MS, Holm BA, Glick PL 1996 Animal models in congenital diaphragmatic hernia. Clin Perinatol 23:813-822

23. Glick PL, Stannard VA, Leach CL, Rossman J, Hosada Y, Morin FC, Cooney DR, Allen JE, Holm B 1992 Pathophysiology of congenital diaphragmatic hernia II: the fetal lamb CDH model is surfactant deficient. J Pediatr Surg 27:382-387

24. Suen HC, Catlin EA, Ryan DP, Wain JC, Donahoe PK 1993 Biochemical immaturity of lungs in congenital diaphragmatic hernia. J Pediatr Surg 28:471-475

25. Brandsma AE, Tibboel D, Vulto IM, Egberts J, Ten Have-Opbroek AA 1993 Ultrastructural features of alveolar epithelial cells in the late fetal pulmonary acinus: a comparison between normal and hypoplastic lungs using a rat model of pulmonary hypoplasia and congenital diaphragmatic hernia. Microsc Res Tech 26:389-399

26. Wilcox DT, Glick PL, Karamanoukian HL, Azizkhan RG, Holm BA 1995 Pathophysiology of congenital diaphragmatic hernia. XII: Amniotic fluid lecithin sphingomyelin ratio and phosphatidylglycerol concentrations do not predict surfactant status in congenital diaphragmatic hernia. J Pediatr Surg 30:410-412

27. Alfanso LF, Arnaiz A, Alvarez FJ, Qi B, Diez-Pardo JA, Vallis-i-Soler A, Tovar JA 1996 Lung hypoplasia and surfactant system immaturity induced in the fetal rat by prenatal exposure to nitrofen. Biol Neonate 69:94-100

28. Wilcox DT, Glick PL, Karamanoukian HL, Holm BA 1997 Contributions by individual lungs to the surfactant status in congenital diaphragmatic hernia. Pediatr Res 41:686-691

29. Mysore MR, Margraf LR, Jaramillo MA, Breed DR, Chau VL, Arevalo M, Moya FR 1998 Surfactant protein A is decreased in a rat model of congenital diaphragmatic hernia. Am J Respir Crit Care Med 157:654-657

30. Coleman C, Zhao J, Gupta M, Buckley S, Tefft JD, Wuenschell CW, Minoo P, Anderson KD, Warburton D 1998 Inhibition of vascular and epithelial differentiation in murine nitrofen-induced diaphragmatic hernia. Am J Physiol 274:L636-L646

31. Losada A, Tovar JA, Xia HM, Diez-Pardo JA, Santisteban P 2000 Down-regulation of thyroid transcription factor-1 gene expression in fetal lung hypoplasia is restored by glucocorticoids Endocrinology 141:2166-2173

32. Benachi A, Chailley-Heu B, Barlier-Mur AM, Dumez Y, Bourbon J 2002 Expression of surfactant proteins and thyroid transcription factor 1 in an ovine model of congenital diaphragmatic hernia. J Pediatr Surg 37:1393-1398

33. Guarino N, Oue T, Shima H, Puri P 2000 Antenatal dexamethasone enhances surfactant protein synthesis in the hypoplastic lung of nitrofen-induced diaphragmatic hernia in rats. J Pediatr Surg 35:1468-1473

34. Shima H, Guarino N, Puri P 2000 Effect of hyperoxia on surfactant protein gene expression in hypoplastic lung in nitrofen-induced diaphragmatic hernia in rats. Pediatr Surg Int 16:473-477 
35. Guilbert TW, Gebb SA, Shannon JM 2000 Lung hypoplasia in the nitrofen model of congenital diaphragmatic hernia occurs early in development. Am J Physiol Lung Cell Mol Physiol 279:L1159-L1171

36. Bratu I, Flageole H, Laberge JM, Possmayer F, Harbottle R, Kay S, Khalife S, Piedboeuf B 2001 Surfactant levels after reversible tracheal occlusion and prenatal steroids in experimental diaphragmatic hernia. J Pediatr Surg 36:122-127

37. Utsuki T, Hashizume K, Iwamori M 2001 Impaired spreading of surfactant phospholipids in the lungs of newborn rats with pulmonary hypoplasia as a model of congenital diaphragmatic hernia induced by nitrofen. Biochim Biophys Acta 1531:90-98

38. Thébaud B, Barlier-Mur AM, Chailley-Heu B, Henrion-Caude A, Tibboel D, DinhXuan AT, Bourbon JR 2001 Restoring effects of vitamin a on surfactant synthesis in nitrofen-induced congenital diaphragmatic hernia in rats. Am J Respir Crit Care Med 164:1083-1089

39. Valls-i-Soler A, Alfonso LF, Arnaiz A, Alvarez FJ, Tovar JA 1996 Pulmonary surfactant dysfunction in congenital diaphragmatic hernia: experimental and clinical findings. Biol Neonate 69:318-326

40. Jonker A, de Boer PA, van den Hoff MJ, Lamers WH, Moorman AF 1997 Towards quantitative in situ hybridization. J Histochem Cytochem 45:413-423

41. Tenbrinck R, Tibboel D, Gaillard JL, Kluth D, Bos AP, Lachmann B, Molenaar JC 1990 Experimentally induced congenital diaphragmatic hernia in rats. J Pediatr Surg 25:426-429

42. Keijzer R, Liu J, Deimling J, Tibboel D, Post M 2000 Dual-hit hypothesis explains pulmonary hypoplasia in the nitrofen model of congenital diaphragmatic hernia. Am J Pathol 156:1299-1306

43. Korfhagen TR, Bruno MD, Glasser SW, Ciraolo PJ, Whitsett JA, Lattier DL, Wikenheiser KA, Clark JC 1992 Murine pulmonary surfactant SP-A gene: cloning, sequence, and transcriptional activity. Am J Physiol 263:L546-L554

44. D'Amore-Bruno MA, Wikenheiser KA, Carter JE, Clark JC, Whitsett JA 1992 Sequence, ontogeny, and cellular localization of murine surfactant protein B mRNA Am J Physiol 262:L40-L47

45. Glasser SW, Korfhagen TR, Bruno MD, Dey C, Whitsett JA 1990 Structure and expression of the pulmonary surfactant protein SP-C gene in the mouse. J Biol Chem 265:21986-21991

46. Moorman AF, De Boer PA, Ruijter JM, Hagoort J, Franco D, Lamers WH 2000 Radio-isotopic in situ hybridization on tissue sections. Practical aspects and quantification. Methods Mol Biol 137:97-115

47. Han RN, Buch S, Freeman BA, Post M, Tanswell AK 1992 Platelet-derived growth factor and growth-related genes in rat lung. II. Effect of exposure to $85 \% \mathrm{O} 2$. Am J Physiol 262:L140-L146

48. Zhou L, Lim L, Costa RH, Whitsett JA 1996 Thyroid transcription factor-1, hepatocyte nuclear factor-3beta, surfactant protein B, C, and Clara cell secretory protein in developing mouse lung. J Histochem Cytochem 44:1183-1193

49. Pringle KC, Turner JW, Schofield JC, Soper RT 1984 Creation and repair of diaphragmatic hernia in the fetal lamb: lung development and morphology. J Pediatr Surg 19:131-140

50. Brandsma AE, ten Have-Opbroek AA, Vulto IM, Molenaar JC, Tibboel D 1994 Alveolar epithelial composition and architecture of the late fetal pulmonary acinus: an immunocytochemical and morphometric study in a rat model of pulmonary hypoplasia and congenital diaphragmatic hernia. Exp Lung Res 20:491-515
51. Janssen DJ, Tibboel D, Carnielli VP, van Emmen E, Luijendijk IH, Wattimena JL, Zimmermann LJ 2003 Surfactant phosphatidylcholine pool size in human neonates with congenital diaphragmatic hernia requiring ECMO. J Pediatr 142:247-252

52. Cogo PE, Zimmermann LJ, Rosso F, Tormena F, Gamba P, Verlato G, Baritussio A, Carnielli VP 2002 Surfactant synthesis and kinetics in infants with congenital diaphragmatic hernia. Am J Respir Crit Care Med 166:154-158

53. Bohn D 2002 Congenital diaphragmatic hernia. Am J Respir Crit Care Med 166:911915

54. Ruijter JM, Hagoort J, De Boer PA, Moorman AF 2001 Calibration of densitometry in radio-isotopic in situ hybridization. Image Anal Stereol 20:219-224

55. Moorman AF, Schumacher CA, de Boer PA, Hagoort J, Bezstarosti K, van den Hoff MJ, Wagenaar GT, Lamers JM, Wuytack F, Christoffels VM, Fiolet JW 2000 Presence of functional sarcoplasmic reticulum in the developing heart and its confinement to chamber myocardium. Dev Biol 223:279-290

56. Schellhase DE, Emrie PA, Fisher JH, Shannon JM 1989 Ontogeny of surfactant apoproteins in the rat. Pediatr Res 26:167-174

57. Losty PD, Pacheco BA, Manganaro TF, Donahoe PK, Jones RC, Schnitzer JJ 1996 Prenatal hormonal therapy improves pulmonary morphology in rats with congenital diaphragmatic hernia. J Surg Res 65:42-52

58. Kitterman JA, Chapin CJ, Vanderbilt JN, Porta NF, Scavo LM, Dobbs LG, Ertsey R, Goerke J 2002 Effects of oligohydramnios on lung growth and maturation in the fetal rat. Am J Physiol Lung Cell Mol Physiol 282:L431-L439

59. Suen HC, Bloch KD, Donahoe PK 1994 Antenatal glucocorticoid corrects pulmonary immaturity in experimentally induced congenital diaphragmatic hernia in rats. Pediatr Res 35:523-529

60. Hedrick HL, Kaban JM, Pacheco BA, Losty PD, Doody DP, Ryan DP, Manganaro TF, Donahoe PK, Schnitzer JJ 1997 Prenatal glucocorticoids improve pulmonary morphometrics in fetal sheep with congenital diaphragmatic hernia. J Pediatr Surg 32:217-221

61. IJsselstijn H, Pacheco BA, Albert A, Sluiter W, Donahoe PK, De Jongste JC, Schnitzer JJ, Tibboel D 1997 Prenatal hormones alter antioxidant enzymes and lung histology in rats with congenital diaphragmatic hernia. Am J Physiol 272:L1059L1065

62. Kapur P, Holm BA, Irish MS, Sokolowski J, Patel A, Glick PL 1999 Lung physiological and metabolic changes in lambs with congenital diaphragmatic hernia after administration of prenatal maternal corticosteroids. J Pediatr Surg 34:354-356

63. Bos AP, Tibboel D, Hazebroek FW, Molenaar JC, Lachmann B, Gommers D 1991 Surfactant replacement therapy in high-risk congenital diaphragmatic hernia. Lancet 338:1279

64. Glick PL, Leach CL, Besner GE, Egan EA, Morin FC, Malanowska-Kantoch A, Robinson LK, Brody A, Lele AS, McDonnell M, Holm B, Rodgers BT, Msall ME, Courey NG, Karp MP, Allen JE, Jewett Jr TC, Cooney DR 1992 Pathophysiology of congenital diaphragmatic hernia. III: Exogenous surfactant therapy for the high-risk neonate with CDH. J Pediatr Surg 27:866-869

65. Lotze A, Knight GR, Anderson KD, Hull WM, Whitsett JA, O’Donnell RM, Martin G, Bulas DI, Short BL 1994 Surfactant (beractant) therapy for infants with congenital diaphragmatic hernia on ECMO: evidence of persistent surfactant deficiency. J Pediatr Surg 29:407-412 